\title{
Open Market Operations in the 1990s
}

Cheryl L. Edwards, of the Board's Division of Monetary Affairs, prepared this article. Gerard Sinzdak provided research assistance.

Open market operations are the Federal Reserve's principal tool for implementing monetary policy. ${ }^{1}$ These purchases and sales of U.S. Treasury and federal agency securities largely determine the federal funds rate - the interest rate at which depository institutions lend balances at the Federal Reserve to other depository institutions overnight. The federal funds rate, in turn, affects monetary and financial conditions, which ultimately influence employment, output, and the overall level of prices.

The objectives and conduct of open market operations have evolved over the years, partly in response to the way the Federal Open Market Committee-the Federal Reserve's primary monetary policymaking body-implements policy and explains it to the public. Also shaping the conduct of open market operations have been changes in financial markets, including a move to arrange transactions in the market for repurchase agreements earlier in the day, prompted by the Federal Reserve's imposition of a fee on daylight overdrafts in the accounts of depository institutions. Another important influence has been a decline in the balances that depository institutions are required to hold at the Federal Reserve stemming from the widespread adoption of retail sweep programs, which transfer funds from deposit accounts that are subject to reserve requirements to deposit accounts that are not.

\section{FEDERAL RESERVE BALANCES AND RESERVE OBJECTIVES}

Open market operations are a powerful tool in implementing monetary policy because of their connection with the total supply of balances at the Federal Reserve and the federal funds rate. Many depository

1. The other tools of monetary policy are reserve requirements and the discount window, the Federal Reserve's lending facility. See Joshua N. Feinman, "Reserve Requirements: History, Current Practice, and Potential Reform," Federal Reserve Bulletin, vol. 79 (June 1993), pp. 569-89, and James A. Clouse, "Recent Developments in Discount Window Policy," Federal Reserve Bulletin, vol. 80 (November 1994), pp. 965-77. institutions maintain accounts at Federal Reserve Banks that they use to make payments on behalf of their customers or themselves. They use the end-ofday balances in these accounts to meet reserve and other balance requirements (See box "Reserve Concepts, Technical Factors, and Required Clearing Balances.") If a depository institution anticipates that it will end the day with a larger balance than it wants, it can reduce that balance in several ways depending on how long it expects the surplus to persist. For example, if it expects the surplus to be temporary, the institution often lends the excess balance overnight to a depository institution that anticipates having a smaller end-of-day balance than it wants. The market in which the lending of Federal Reserve balances takes place is the federal funds market, and the interest rate at which the loan is made is the federal funds rate. ${ }^{2}$ The total supply of Federal Reserve balances available to depository institutions is determined primarily by open market operations. Through these operations, the Federal Reserve has considerable influence over conditions in the federal funds market.

Open market operations can be directed at achieving a desired quantity of balances, as specified by the Federal Open Market Committee (FOMC), or a desired price (federal funds rate), but they may not be able to achieve both at once. The greater the emphasis on a quantity objective, the more short-run changes in the demand for balances will influence the federal funds rate; conversely, the greater the emphasis on a funds-rate objective, the more shifts in demand will influence the quantity of Federal Reserve balances.

Over the years, the Federal Reserve has used variations of both approaches to open market operations. ${ }^{3}$

2. Federal funds lending is not collateralized; therefore, different depository institutions pay different rates for loans depending on their creditworthiness. Depository institutions can arrange transactions directly between themselves, or for large transactions they can use a federal funds broker. Typically, the term "federal funds rate" refers to the rate at which the most creditworthy institutions borrow and lend balances in the brokered market.

3. Detailed discussions of the history of monetary policy can be found in Ann-Marie Meulendyke, U.S. Monetary Policy and Financial Markets (New York: Federal Reserve Bank of New York, 1989), pp. 18-47, and in Ann-Marie Meulendyke, "A Review of Federal Reserve Policy Targets and Operating Guides in Recent Decades," Federal Reserve Bank of New York Quarterly Review, vol. 13 (Autumn 1988), pp. 6-17. 


\section{Reserve Concepts, Technical Factors, and Required Clearing Balances}

\section{Reserve Concepts}

Total reserves equal vault cash used by depository institutions to meet reserve requirements (so-called applied vault cash) plus reserve balances held by depository institutions at their Federal Reserve Banks. Reserve balances, and thus total reserves, exclude required clearing balances of depository institutions.

\section{Demand for Reserves}

The demand for reserves has two components, required reserves and excess reserves.

Required Reserves (RR). Each depository institution must hold a percentage of certain of its deposit liabilities as reserves. Reserve requirements are currently applied to the average level of transaction deposits over a two-week computation period and are specified as an average level to be maintained over a two-week reserve maintenance period. ${ }^{1}$ A depository institution's reserve requirement is satisfied first by its vault cash-currency held in its vault-and, if vault cash is insufficient, by the end-of-day balances it maintains during the reserve maintenance period in its account at its Federal Reserve Bank. Holding required reserve balances - the difference between required reserves and applied vault cash - is costly for a depository institution because the Federal Reserve does not pay interest on these balances.

Excess Reserves (ER). A depository institution may choose to hold balances at its Federal Reserve Bank in addition to those it must hold to meet reserve requirements; these balances are called excess reserves. Depository institutions hold excess reserves to avoid deficiencies in their required reserve balances and to avoid overnight overdrafts, both of which are subject to charges. In general, depository institutions hold few excess reserves because these holdings do not earn interest. Most excess reserves are held by small depository institutions for whom the cost of very close management of reserve balances would exceed the interest they could earn by holding fewer excess reserves. Vault

1. Approximately 99 percent of all required reserves are held by depository institutions that meet their reserve requirements on a two-week average basis. The computation and maintenance periods for these depository institutions are nearly contemporaneous. Small depository institutions hold the remaining required reserves. The computation and maintenance periods for these institutions are one-week long, but there is a lag between the two periods. cash held in excess of reserve requirements is not included in excess reserves or in total reserves.

\section{Supply of Reserves}

The supply of reserves has two components, borrowed reserves and nonborrowed reserves.

Borrowed Reserves (BR). Borrowed reserves are balances provided to depository institutions through the Federal Reserve's discount window lending facility. In general, a depository institution is expected to use the discount window to meet its liquidity needs only after drawing on all other reasonably available sources of funds. This administrative criterion limits considerably the use of the window, even though the rate charged for discount window loansthe discount rate-is typically below the federal funds rate. Since the mid-1980s, depository institutions have become quite reluctant to turn to the discount window because of concerns that their borrowing might become known to private market participants-even though the Federal Reserve treats the identity of borrowers in a highly confidential manner-and that such borrowing might be viewed as a sign of weakness. ${ }^{2}$ As a result, the volume of balances supplied through the discount window is generally a very small fraction of the total supply of reserves.

Nonborrowed Reserves (NBR). Nonborrowed reserves are reserves provided to depository institutions through means other than the discount window and include applied vault cash. Over time, nonborrowed reserves are affected primarily by open market operations. They are also influenced by changes in technical factors (described below). Although the Federal Reserve does not have complete control over technical factors, it can offset fairly closely their effects on nonborrowed reserves through open market operations, and thus it can exercise considerable control over the supply of reserves.

In equation form, the reserve concepts are related as follows:

$$
T R=R R+E R=B R+N B R .
$$

At equilibrium, the total demand for reserves must equal the total supply of reserves.

2. See Clouse, "Recent Developments in Discount Window Policy."
During most of the 1970s, it targeted the federal funds rate. In October 1979, at a time when antiinflationary restraint was called for, it began instead to target the quantity of reserves-specifically, nonborrowed reserves - to achieve greater control over M1, the narrowest measure of the money stock.
Under this approach, market interest rates varied over a wide range, mainly in response to deviations in M1 growth from the FOMC's objective.

By late 1982, it had become clear that financial innovation had weakened the historical link between M1 and the economic objectives of monetary policy, 


\section{Reserve Concepts, Technical Factors, and Required Clearing Balances—Continued}

\section{Technical Factors Affecting Nonborrowed Reserves}

Technical factors are items on the Federal Reserve's balance sheet other than loans and holdings of domestic securities that can affect the supply of nonborrowed reserves to depository institutions. ${ }^{3}$ The key factors are described here.

Currency. The Federal Reserve supplies currency to depository institutions. When it does so, it debits the Federal Reserve account of the depository institution receiving the currency, thus draining reserve balances from the depository system. The amount of currency demanded by the public, both in the United States and abroad, tends to grow over time, in part reflecting increases in nominal spending. Consequently, an increasing volume of reserve balances is drained from the depository system and must be replenished. The expansion of currency outstanding is the primary reason the Desk conducts outright purchases of securities.

Treasury Balance. The U.S. Treasury maintains an account at the Federal Reserve. When a payment is made to the Treasury, the Federal Reserve account of the depository institution on which the payment is drawn is debited, and the Federal Reserve account of the Treasury is credited. The Treasury is not a depository institution, so the transaction drains reserve balances from the depository system. The Treasury's Federal Reserve balance is the most volatile technical factor that affects nonborrowed reserves, especially in the weeks following the April 15 deadline for federal income tax payments.

Federal Reserve Float. Federal Reserve float is created when the account of the depository institution presenting a check for payment is credited before the account of the depository institution on which the check is drawn is debited. This situation can arise because credit is granted to the presenting depository institution on a preset schedule, whereas the paying institution's account is not debited until

3. A more detailed discussion of the factors affecting nonborrowed reserves can be found in Ann-Marie Meulendyke, U.S. Monetary Policy and Financial Markets, pp. 141-47. the check is physically presented to it. Float temporarily adds reserve balances to the depository system because, until the paying institution's account is debited, the two depository institutions essentially are credited with the same reserve balances. Float is most volatile following inclement weather that disrupts the normal check-delivery process.

Foreign Exchange. When the Federal Reserve purchases dollars, it does so by selling assets denominated in foreign currencies. It debits the account of the purchaser of the foreign currency asset (or the purchaser's depository institution if the purchaser is not a depository institution) for the dollar value of the transaction, so reserve balances decrease. Conversely, when the Federal Reserve sells dollars, it purchases assets denominated in foreign currencies. It credits the account of the seller's depository institution for the dollar value of the transaction, and reserve balances increase. The effects of these transactions on reserve balances are sterilized, or offset, by open market operations.

\section{Required Clearing Balances}

Depository institutions that use Federal Reserve priced services (such as check clearing or electronic payment services) may establish required clearing balances at their Federal Reserve Banks. When a depository institution establishes a required clearing balance, it commits in advance to holding a specified balance, above its required reserve balance, on average over the reserve maintenance period. Required clearing balances, like excess reserves, provide a cushion against overnight overdrafts; unlike excess reserves, however, required clearing balances earn implicit interest, in the form of earnings credits. If the depository institution fails to satisfy its required clearing balance, the deficiency is subject to a charge.

Although they are excluded from reserve measures because they cannot be used to meet reserve requirements, required clearing balances play an important role in helping depository institutions avoid overnight overdrafts. For the Desk's purposes, required clearing balances are included in nonborrowed reserves as a technical factor absorbing reserves. and the FOMC began to make more discretionary decisions about money market conditions, using a wider array of economic and financial variables to judge the need for an adjustment in short-term interest rates. In the day-to-day conduct of open market operations, this change was manifested in a shift of focus from a nonborrowed reserve target to a borrowed reserve target. The Federal Reserve routinely supplies fewer reserves than the estimated demand, thus forcing depository institutions to meet their remaining need for reserves by borrowing at the discount window. The total amount borrowed is limited, however, even though the discount rate is generally below the federal funds rate, because access to discount window credit is restricted. In particular, depository institutions are required to pursue all other reasonably available sources of funds, including those available in the federal funds market, before credit is granted. During the time it was targeting borrowed reserves, the Federal Reserve influenced the level of 
the federal funds rate by controlling the extent to which depository institutions had to turn to the discount window. When it wanted to ease monetary policy, it would reduce the borrowed reserve target and supply more nonborrowed reserves to meet estimated demand. With less pressure to borrow from the discount window, depository institutions would bid less aggressively for reserve balances at the Federal Reserve, and the federal funds rate would fall.

Beginning in the mid-1980s, spreading doubts about the financial health of some depository institutions led to an increasing reluctance on the part of many institutions to borrow at the discount window, thus weakening the link between borrowing and the federal funds rate. ${ }^{4}$ Consequently, the Federal Reserve increasingly sought to attain a specific level of the federal funds rate rather than a targeted quantity of borrowed reserves.

In early 1994, the FOMC was preparing to tighten monetary policy for the first time in five years, and it wanted the public to understand its objectives as quickly and clearly as possible. For many years, the FOMC did not announce changes in the stance of monetary policy. Instead, market participants had to infer changes from the type of open market operation conducted and the level of the federal funds rate relative to their perceptions about the FOMC's target rate. The perceived change would then be publicized through wire service stories and other press accounts. This means of communicating could, and on a few occasions did, lead to misunderstandings about the stance of policy or to delays in recognizing changes. As a result, the FOMC in 1994 began announcing changes in its policy stance, so that the public would learn of any change immediately. In 1995, it sought to make its announcements even clearer by explicitly stating its short-term objective for open market operations, which is currently a target level for the federal funds rate.

\section{OPEN MARKET OPERATIONS: AN OVERVIEW}

Open market operations affect the supply of Federal Reserve balances to depository institutions. Purchases of securities increase the quantity of Federal Reserve balances because the Federal Reserve creates the balances to pay the seller by crediting the account of

\footnotetext{
4. See Clouse, "Recent Developments in Discount Window Policy." See also "Monetary Policy and Open Market Operations during 1988," Federal Reserve Bank of New York Quarterly Review, vol. 14 (Winter-Spring 1989), pp. 83-102.
}

the seller's depository institution at the Federal Reserve. Conversely, sales of securities decrease the quantity of Federal Reserve balances because the Federal Reserve extinguishes balances when it debits the account of the purchaser's depository institution at the Federal Reserve. In contrast, when financial institutions, business firms, or individuals conduct transactions among themselves, they simply redistribute existing balances held at the Federal Reserve without changing the aggregate level of those balances. ${ }^{5}$

\section{Domestic Securities Holdings}

Open market operations are arranged by the Domestic Trading Desk at the Federal Reserve Bank of New York (the Desk) under authorization from the FOMC, which was created by statute to direct open market operations. Operations are conducted in domestic securities, primarily U.S. Treasury and federal agency securities. ${ }^{6}$ Nearly all of the Federal Reserve's domestic securities holdings are Treasury securities, with roughly equal shares of Treasury bills and Treasury coupon securities-notes and bonds (table 1). Federal agency securities have accounted for only a small proportion of the domestic securities portfolio since the Federal Reserve began purchasing such securities in 1971. The Desk has not added to the Federal Reserve's permanent holdings of agency securities through open market purchases since 1981; moreover, when suitable replacements for maturing issues have not been offered, the Desk has had to allow existing holdings to mature without replacement. As a result, the Federal Reserve's holdings of federal agency securities have declined steadily, and recently the Desk stated that it will permit the remainder of these holdings to mature without replacement. It continues, however, to acquire agency securities in temporary operations, which are discussed below.

\footnotetext{
5. More detailed discussions of open market operations can be found in Meulendyke, U.S. Monetary Policy and Financial Markets, and in M.A. Akhtar, Understanding Open Market Operations (New York: Federal Reserve Bank of New York, 1997).

6. The Desk is also authorized to conduct limited operations in bankers' acceptances, and it was very active in that market until 1977 , when the FOMC decided to discontinue outright purchases under ordinary circumstances. Outright transactions in bankers' acceptances had not contributed materially to meeting reserve needs for a number of years, and the FOMC noted that the market had become mature and efficient and no longer needed support from Federal Reserve operations. Similar motivations prompted the FOMC to discontinue temporary purchases of bankers' acceptances in 1984.

The Federal Reserve also holds securities denominated in foreign currencies. Purchases and sales of these securities are not considered open market operations.
} 
1. Federal Reserve holdings of U.S. Treasury and federal agency securities, September 24, 1997

Billions of dollars

\begin{tabular}{|c|c|}
\hline Type of security & Holding \\
\hline Treasury bills ${ }^{1}$ & 209.6 \\
\hline Treasury coupon securities ... & 216.5 \\
\hline Notes $\ldots \ldots \ldots \ldots \ldots \ldots$ & 161.5 \\
\hline Bonds .......... & 55.0 \\
\hline Federal agency $\ldots \ldots \ldots \ldots$ & .9 \\
\hline Total Treasury and agency & 427.0 \\
\hline
\end{tabular}

1. Includes Treasury bills sold under matched sale-purchase transactions.

The overall size of the Federal Reserve's portfolio of domestic securities is dictated by the FOMC's monetary policy objectives. The liquidity and maturity of that portfolio depend on the FOMC's preferences, which have evolved over time. In the early 1980 s, the average maturity of the portfolio was slightly more than four years, similar to the average maturity of the public's holdings of marketable U.S. Treasury debt (table 2). In 1984, when Continental Illinois National Bank faced a severe liquidity crisis, emphasis on the liquidity of the portfolio increased because the Desk had to offset the massive volume of balances provided to Continental through the discount window. The Federal Reserve was able to maintain the desired level of reserve balances by allowing Treasury bills to mature without replacement and by selling them in a market that was receptive to liquid short-term issues of the highest quality. The crisis underscored the importance of having a liquid portfolio, one that could accommodate developments requiring large cuts in holdings over a short period. Over the next seven years, the average maturity trended down as the Desk purchased more Treasury bills than Treasury coupon issues on balance. ${ }^{7}$ By the end of 1991, the average maturity of the portfolio was just under three years.

In the spring of 1992, the FOMC reviewed the maturity structure of the Federal Reserve's portfolio holdings. It concluded that the portfolio was sufficiently liquid and directed the Desk to take steps to keep the average maturity from falling further. Following a further review in September 1996, the FOMC confirmed its view that the primary objective in managing the composition of the Federal Reserve's domestic securities portfolio was to ensure a high degree of liquidity.

7. The notable exception in this downtrend occurred in 1989, when the average maturity ticked up. Heavy purchases of foreign currency by the Federal Reserve injected more reserve balances into the depository system than were consistent with reserve objectives, and the Desk absorbed the overabundance through sales of Treasury bills.
2. Average maturity of marketable U.S. Treasury securities, selected years, 1975-97

Months

\begin{tabular}{|c|c|c|}
\hline Year & $\begin{array}{c}\text { Federal Reserve } \\
\text { holdings }\end{array}$ & $\begin{array}{l}\text { Holdings of } \\
\text { private investors }\end{array}$ \\
\hline 1975 & 31 & 29 \\
\hline 1980 & 54 & 45 \\
\hline $1985 \ldots$ & 47 & 60 \\
\hline 1990 & 39 & 71 \\
\hline 1991 & 35 & 72 \\
\hline $1992 \ldots$ & 36 & 70 \\
\hline 1993 & 38 & 68 \\
\hline 1994 & 38 & 66 \\
\hline 1995 & 39 & 63 \\
\hline 1996 & 41 & 63 \\
\hline 1997 & 42 & 64 \\
\hline
\end{tabular}

NotE. End-of-year data except 1997; for 1997, end-of-June data. Federal Reserve holdings exclude the effects of securities acquired and sold in temporary transactions.

SourcE. Federal Reserve Bank of New York and Treasury Bulletin.

\section{Counterparties}

The FOMC's authorization to conduct open market operations permits the Desk to conduct business with foreign official and international institutions that maintain accounts at the Federal Reserve Bank of New York and with securities dealers. The dealers with which the Desk transacts business are called primary dealers. For many years, primary dealers were expected to meet market share and capital requirements, to bid meaningfully for new securities at U.S. Treasury auctions, and to permit review of their dealer activities by the Federal Reserve through statistical and financial reporting and on-site visits. ${ }^{8}$ In addition to being invited to bid in open market operations, primary dealers, unlike other dealers, were allowed to bid on behalf of customers at all Treasury auctions and to bid at Treasury note and bond auctions without first making a deposit or obtaining a guarantee. The practice of transacting with a limited number of dealers was intended to foster the development of active and liquid secondary markets for Treasury debt, to promote vigorous bidding at Treasury auctions, and to ensure that the Federal Reserve had counterparties who could handle its large orders efficiently and safely.

In 1991, following disclosures of bidding irregularities at Treasury auctions by Salomon Brothers, Inc., the Treasury, the Securities and Exchange Commission, and the Federal Reserve reviewed many aspects of the market for Treasury securities, includ-

8. See also "Monetary Policy and Open Market Operations during 1991," Federal Reserve Bank of New York Quarterly Review, vol. 17 (Spring 1992), pp. 1-24. 


\section{Estimating the Need for Open Market Operations}

The first step in estimating the need for open market operations is constructing the nonborrowed reserve objective. Rearranging the equation that defines reserve concepts,

$$
N B R=R R+E R-B R .
$$

The demand for required reserves $(R R)$ is estimated by staff at the Federal Reserve Bank of New York and at the Board of Governors on the basis of data on deposits reported by depository institutions. The Desk assumes that the demand for excess reserves $(E R)$ will be $\$ 1$ billion, but it sometimes adjusts that figure as the maintenance period progresses on the basis of econometric models and data on holdings of excess reserves by type of depository institution (for example, large banks, small banks, thrift institutions, and U.S. branches of foreign banks). The supply of borrowed reserves $(B R)$ is estimated by the Desk as the amount of reserve balances to be supplied through the discount window that is consistent with the difference between the discount rate and the FOMC's target federal funds rate. Most discount window borrowing is done under the seasonal program, and the interest rate charged is a floating, market-based rate; such borrowing rises in the spring (as loans are extended during the planting season), peaks in the summer, and tapers off in the fall (as loans are repaid after the harvest). Once these three estimates are available, the equation is used to construct the nonborrowed reserve objective. For example, if required reserves are estimated at $\$ 47.5$ billion, the demand for excess reserves is assumed to be $\$ 1$ billion, and borrowed reserves are estimated at $\$ 0.4$ billion, then the nonborrowed reserve objective for the period is $\$ 48.1$ billion.

The second step is forecasting the supply of nonborrowed reserves in the absence of any additional open market operations over the remainder of the maintenance period. These forecasts, which are provided to the Desk by staff at the New York Reserve Bank and the Board, include an estimate of the amount of vault cash that depository institutions will use to meet their reserve requirements.

The amount of reserve balances that must be added or drained through open market operations each day, on average, over the entire reserve maintenance period is the difference between the nonborrowed reserve objective and the projected supply of nonborrowed reserves. If the projected supply exceeds the objective, the Desk must drain reserve balances during the period. If the objective exceeds the projected supply, the Desk must add reserve balances; for example, if the staff estimates that the supply of nonborrowed reserves is $\$ 44.1$ billion for the period and the objective is $\$ 48.1$ billion, then the Desk needs to add a daily average of $\$ 4$ billion over the maintenance period. ing the primary dealer system. ${ }^{9}$ The review prompted the Federal Reserve to establish a more open system of trading relationships based primarily on the value of the dealers as counterparties for the Federal Reserve and the Treasury. The Federal Reserve dropped the market share criterion, which was viewed by some market participants as a barrier, and discontinued its dealer surveillance function, in part to emphasize that the Federal Reserve does not regulate primary dealers. As it always has, the Federal Reserve does require that primary dealers be active and competitive participants in open market operations and that they be consistent and meaningful participants in Treasury auctions. It also requires that primary dealers meet the capital standards of their primary regulators rather than a standard set by the Federal Reserve. In addition, primary dealers must freely and candidly supply the Desk with information on market activity. The joint agency review also prompted the Treasury to change its auction procedures, extending to other dealers the privileges once enjoyed only by primary dealers. The number of

9. The findings of the review are reported in Joint Report on the Government Securities Market (Washington, D.C.: Government Printing Office, January 1992). primary dealers currently is close to its 1991 level: Some dealers have been added to the list, while a few have either exited the business or merged with other primary dealers.

\section{THE DAILY CONDUCT OF OPEN MARKET OPERATIONS}

Each morning, the staff at the Domestic Trading Desk decide whether an open market operation is necessary and, if so, whether it should be an outright or a temporary operation.

\section{Determining the Need for an Operation}

Staff at the Federal Reserve Bank of New York and at the Board of Governors provide the Desk with estimates of the average supply of and demand for reserves for the current two-week reserve maintenance period (and two future periods), along with the daily estimates that underlie the averages for the current period. The estimates of period-average reserve demand, less an allowance for discount win- 
dow borrowing consistent with the federal funds rate target, yield an objective for nonborrowed reserves. (See box "Estimating the Need for Open Market Operations.") This objective is modified as the maintenance period progresses to incorporate new information on reserve demand or borrowing. The objective is compared with the projected supply of nonborrowed reserves absent any additional open market operations during the maintenance period. The difference between the objective and the projected supply indicates the amount of reserve balances that must be added or drained each day, on average, over the entire maintenance period: If the objective for nonborrowed reserves exceeds the projected supply, the Desk needs to add reserve balances; if the projected supply of nonborrowed reserves exceeds the objective, the Desk needs to drain reserve balances. The points during the maintenance period at which reserve balances are added or drained and the types of operations conducted depend importantly on the expected duration and daily pattern of the reserve need.

\section{Outright Operations}

If staff projections indicate a large and persistent imbalance between reserve demand and supply, say for a month or more, the Desk may conduct an outright purchase or sale of securities. (See box "Types of Open Market Operations.") Such transactions increase or decrease the size of the Federal Reserve's portfolio (and thus add or drain reserve balances) permanently. The Desk conducts far more outright purchases than outright sales, primarily because it must offset the reserve drain resulting from the public's increasing demand for currency.

Before 1995, the Desk entered the market to conduct outright operations only a few times each year. It would wait until reserve needs were large enough to warrant a sizable transaction-on the order of $\$ 3$ billion to $\$ 4$ billion - in part because such operations, especially coupon purchases, were time consuming. For a coupon purchase, for example, the Desk had to review numerous offers on about two hundred securities. (The number and volume of outright purchases in recent years are shown in table 3.) Automation of the bidding process in 1994 decreased the time needed to evaluate offers, but dealers still had to wait a significant amount of time between submitting offers and learning whether their offers had been accepted. For that reason, dealers, in pricing their offers, took into account the risk that market prices might move adversely while they were
3. Outright purchases in the market, 1990-97

\begin{tabular}{c|c|c|c|c}
\hline \multirow{2}{*}{ Year } & \multicolumn{2}{|c|}{ Treasury bills } & \multicolumn{2}{c}{ Treasury coupon securities } \\
\cline { 2 - 5 } & $\begin{array}{c}\text { Number of } \\
\text { market entries }\end{array}$ & $\begin{array}{c}\text { Volume } \\
\text { (billions of } \\
\text { dollars) }\end{array}$ & $\begin{array}{c}\text { Number of } \\
\text { market entries }\end{array}$ & $\begin{array}{c}\text { Volume } \\
\text { (billions of } \\
\text { dollars) }\end{array}$ \\
\hline $1990 \ldots \ldots$ & 5 & 16.6 & 0 & $\ldots$ \\
$1991 \ldots \ldots$. & 3 & 8.1 & 1 & 2.3 \\
$1992 \ldots \ldots \ldots$ & 3 & 9.7 & 3 & 12.3 \\
$1993 \ldots \ldots \ldots$ & 2 & 8.6 & 4 & 16.8 \\
$1994 \ldots \ldots \ldots$ & 2 & 7.7 & 4 & 17.0 \\
$1995 \ldots \ldots .$. & 2 & 8.2 & 5 & 9.1 \\
$1996 \ldots \ldots \ldots$ & 2 & 9.8 & 5 & 7.2 \\
$1997 \ldots \ldots \ldots$ & 1 & 4.0 & 13 & 17.4 \\
\hline
\end{tabular}

Note. Data for 1997 are through September 24.

waiting. In November 1995, the Desk changed its approach to outright coupon purchases. It now divides up a purchase of coupon securities, focusing on only a portion of the maturity spectrum rather than on all maturities at once. This approach has further decreased the turnaround time for such operations and has likely resulted in better prices to the Desk. The Desk still purchases all maturities of Treasury coupon issues, but it generally spreads its purchases over several weeks, in keeping with the size of estimated reserve needs. With this new procedure, the Desk is better able to tailor its purchases to reserve needs. In addition, the operations, which had been conducted only in the early afternoon, can now be conducted in the morning as well.

\section{Temporary Operations}

If staff projections indicate only a short-lived need to add or drain reserve balances, the Desk usually conducts a temporary operation. Such operations are far more common than outright operations, partly because daily fluctuations in technical factors alter reserve supply (as discussed in the box "Reserve Concepts, Technical Factors, and Required Clearing Balances"). The daily demand for reserves is generally assumed to be equal to the period-average level, but the figure is informally adjusted on days on which reserve demand has historically appeared to be elevated, such as on days on which social security payments are made. Although reserves are held on a two-week average basis, a large imbalance between demand and supply on any one day may cause the federal funds rate to move significantly away from the FOMC's target. Temporary open market operations help to offset such large daily imbalances. The Desk arranges repurchase agreements to add reserve balances temporarily and matched sale-purchase transactions to drain reserve balances temporarily. 


\section{Types of Open Market Operations}

Most open market operations are conducted in the market with the thirty-nine securities dealers that are designated "primary dealers;" some are conducted with foreign official and international institutions that maintain accounts at the Federal Reserve Bank of New York. All operations in the market are conducted as auctions, with all primary dealers invited to bid, and the bidding and bid evaluation processes are now automated. Since January 1997, the Desk has reported the par value of each of its open market operations with primary dealers at the conclusion of the operation.

\section{Outright Operations}

The Desk may not add to the Federal Reserve's holdings of securities by purchasing new securities when they are first auctioned because it has no authority to lend directly to the Treasury. ${ }^{1}$ Therefore, it must make any additions to holdings through purchases from primary dealers in the secondary market or directly from foreign official and international institutions.

Purchases and Sales in the Market. When purchasing or selling securities in the secondary market, the Desk entertains from primary dealers bids on all securities of a particular type (Treasury bills or Treasury coupon securities) and, for coupon securities, in a particular portion of the maturity spectrum. In determining which bids to accept, the Desk considers the bids that represent the highest yield (for purchases) or the lowest yield (for sales) relative to the prevailing yield curve. To avoid holding too large a share of any one issue, the Desk also considers the size of its holdings of the particular issue relative to the total amount outstanding.

Outright sales in the market are infrequent; the most recent one occurred in 1990. For many years, the Desk often sold Treasury bills in late January to absorb a surfeit of reserves resulting from seasonal declines in currency outstanding and in required reserves. In the 1990s, strong overseas demand for U.S. currency generally has offset the seasonal decline in currency outstanding, obviating the need for outright sales.

1. It may exchange its maturing holdings for new securities at auction, however, and it does so routinely.
Purchases from and Sales to Foreign and International Accounts. Purchases from and sales to foreign and international accounts enable the Desk to make small adjustments to the Federal Reserve's securities holdings without formally entering the market. ${ }^{2}$ Purchases from these accounts were fairly common until 1996, when the Desk decided to make most of its purchases in the secondary market from primary dealers so that its operations would be more transparent. Also, the recent shift to purchasing securities in the market in a particular portion of the maturity spectrum has given the Desk the flexibility to add to the Federal Reserve's portfolio more gradually, thus reducing the need to rely on transactions with foreign and international accounts for this purpose. Sales to these accounts have been infrequent in the 1990s because of the strong demand for currency. The sizes of purchases from and sales to foreign and international accounts are not explicitly reported to the public, though they can be inferred from changes in the Federal Reserve's holdings of domestic securities. ${ }^{3}$

Redemptions. The Desk can choose to reduce the size of the Federal Reserve's holdings by redeeming some of its maturing securities rather than exchanging all of them for new securities. Such an approach makes it possible to reduce the portfolio gradually without formally entering the market. When replacement securities are not available, the Desk must redeem its maturing holdings.

\section{Temporary Operations}

An operation is temporary if the transaction will, under the contract, unwind after a specified number of days. Temporary open market operations help to offset short-lived imbalances between reserve supply and demand. The Desk arranges repurchase agreements to add reserve balances temporarily and matched sale-purchase transactions to drain reserve balances temporarily.

2. The price at which these transactions occur is the midpoint between the bid and the ask price in the secondary market.

3. Federal Reserve statistical release H.4.1, Factors Affecting Reserve Balances of Depository Institutions and Condition Statement of F.R. Banks, which is published each Thursday, provides data on the Federal Reserve's domestic securities portfolio and other factors affecting the reserve balances of depository institutions. These data are also provided monthly in tables 1.11 and 1.18 of the Federal Reserve Bulletin.
For more than seventeen years, the Desk entered the market to arrange temporary transactions between 11:30 a.m. and 11:45 a.m. This time was selected because it gave staff members at the Board and the New York Reserve Bank time at the beginning of the business day to assemble data on factors affecting reserve supply and demand and to make their fore- casts. Although the market for repurchase agreements was somewhat more active earlier in the day, it was usually sufficiently active at this time to accommodate open market operations. Nonetheless, there was a risk that the volume of offers on the operation would not be sufficient to allow the Desk to inject the desired amount of reserve balances into the deposi- 


\section{Types of Open Market Operations-Continued}

\section{Repurchase Agreements}

When the Desk arranges a repurchase agreement, it purchases securities from a primary dealer (or the dealer's customer) and agrees to resell the securities to the dealer (or customer) on a specified date. The Desk arranges two types of repurchase agreements: System and customer-related. For both types, the Desk solicits offers from primary dealers. The dealers may make offers on their own behalf or on behalf of their customers. The offers set forth a rate and an amount of repurchase agreements that the dealer (or its customer) is prepared to transact. ${ }^{4}$ The Desk ranks the bids in descending order of rate. It accepts the offer with the highest rate first and continues to accept lower rates until the total volume of offers equals the amount of reserve balances that the Desk wants to inject into the depository system. If a greater quantity is offered at the lowest rate than is needed to attain the desired quantity, the offers at that rate are prorated.

System Repurchase Agreements. The Desk does not announce the intended size of the operation when it solicits offers. The dealer (or customer) whose offer is accepted sends securities (Treasury or federal agency) to the Federal Reserve Bank of New York, and the Bank pays for them by creating balances in the Federal Reserve account of the dealer's (or the dealer's customer's) clearing bank.

System repurchase agreements are conducted on an overnight or term basis. Term repurchase agreements may last no longer than fifteen days and may be either withdrawable or fixed term. If the agreement is withdrawable, the dealer has the option of asking, before 10:00 a.m. on any day before the agreement concludes, for the return of its securities; it usually does so if financing rates fall below the rate arranged with the Desk. If the repurchase agreement is fixed term, the dealer may not withdraw its securities early.

Until February 1994, when the FOMC began announcing changes in its policy stance, overnight System repurchase agreements were often used to signal an easing of monetary policy. Term System repurchase agreements, in contrast, were considered more technical, though the Desk generally refrained from such operations when the federal funds rate was noticeably below the FOMC's target, so as not to mislead market participants about the stance of policy.

Customer-Related Repurchase Agreements. Customerrelated repurchase agreements are a type of transaction

4. The price at which the Federal Reserve temporarily purchases the securities is that day's market price. This price and the rate quoted by the dealer determine the price at which the Federal Reserve resells the securities. arranged by the Desk with primary dealers on behalf of foreign official and international institutions that maintain accounts at the Federal Reserve Bank of New York.

These institutions maintain accounts at the New York Reserve Bank to help manage their U.S. dollar payments and receipts. The Federal Reserve provides a means by which the cash balances in these accounts can be invested overnight. The accounts purchase securities from the Federal Reserve's portfolio and simultaneously agree to resell the securities the next business day at prices that give the accounts a market-based rate of return. Reserve balances are drained when balances in these accounts rise. When the Desk wants to replenish reserve levels, it may decide to pass these accounts' purchase requests through to primary dealers as customer-related repurchase agreements.

Customer-related repurchase agreements were first used in 1974 and were quite common until recently. In December 1996, the Desk announced that it would no longer routinely conduct these operations, and it did not conduct any over the first nine months of 1997 . When the Desk did conduct these transactions, it announced the intended size of the operation to dealers but usually did not report the final accepted amount. The operations were generally smaller than operations involving System repurchase agreements; the maximum size was limited by the volume of purchase requests. The maturity of these agreements was generally overnight because participation in the investment facility changed each day. These operations were viewed as technical in nature and as a signal of satisfaction with the level of the federal funds rate.

\section{Matched Sale-Purchase Transactions}

Matched sale-purchase transactions (which are akin to reverse repurchase agreements) are the method by which the Federal Reserve drains reserve balances temporarily. They were first used in 1966. In these transactions, the Federal Reserve agrees to sell a short-dated Treasury bill at a specified price, and the buyer simultaneously enters into another agreement to sell the bill back to the Federal Reserve on a specific date.

In a matched sale-purchase transaction, the Desk indicates the bill and the rate at which it will sell the bill. Dealers then submit offers for the amount of the bill they will buy and the rate at which they will resell it to the Desk. The Desk accepts the highest rate first (so that it buys back the bill at the lowest price) and continues to accept lower rates until the total of accepted offers equals the amount of reserve balances that it wants to drain. tory system, particularly when reserve needs were large. At times when the risk was high, the Desk might enter the market before its customary interven- tion time or might preannounce the operation on the preceding afternoon to try to ensure that the volume of offers would be adequate. 
In 1994, the Federal Reserve began charging a fee for daylight overdrafts in depository institutions' Federal Reserve accounts. ${ }^{10}$ Securities dealers, who now faced fees on the daylight overdrafts in their accounts with depository institutions, began arranging and settling more of their financing transactions earlier in the day to reduce their daylight overdrafts. The Desk, in turn, sought to align its market entry more closely with the period of greatest market activity, and in January 1997, after an acceleration of Federal Reserve data flows and modifications to processing procedures, it moved its intervention time to around 10:30 a.m.

Shifts in the short-run target for open market operations have influenced the number of times the Desk enters the market each day to conduct temporary transactions and the role of reserve estimates in determining the amount of reserve balances to be supplied. In the 1970s, when the target was the federal funds rate, the Desk frequently entered the market several times a day. Although reserve estimates generally guided decisions about the quantity of reserve balances to be supplied, the Desk responded to any deviation of the federal funds rate from target, regardless of the reserve estimates, up until its intervention window closed in the early afternoon. During the 1979-82 period, when the target was nonborrowed reserves, the Desk entered the market at most once a day. Estimates of reserve supply and demand were essential in determining the quantity of reserve balances to be supplied. At the time of this single market entry, the Desk typically conducted only one operation, although at times it conducted two operations with different terms, such as four- and seven-day repurchase agreements. Since late 1982, as procedures have evolved and the federal funds rate again has become the short-run target for open market operations, the Desk has continued, generally, to enter the market at most once a day to conduct temporary transactions, and at times to conduct two operations with different terms. Estimates of reserve supply and demand continue to play a role in determining the amount of reserve balances to supply in order to keep the federal funds rate close to the FOMC's target level. It is possible that the Desk will enter the market several times on any given day when reserve needs warrant, but multiple market entries are not expected to become routine. The Desk entered the market

10. For a discussion of the reasons for the Federal Reserve's imposition of fees for daylight overdrafts and the response to these fees, see Heidi Willmann Richards, "Daylight Overdraft Fees and the Federal Reserve's Payment System Risk Policy," Federal Reserve Bulletin, vol. 81 (December 1995), pp. 1065-77. more than once to arrange repurchase agreements on only two days in the first nine months of 1997.

\section{CHANGES IN THE DEMAND FOR BALANCES AND THEIR IMPLICATIONS}

Innovations in the 1990s have reduced required reserve balances. Although depository institutions have increased the amount of balances they contract to hold in the form of required clearing balances, total required balances have dropped to historically low levels. This development has implications for the conduct of open market operations and for the federal funds rate.

\section{High Total Required Balances}

Until the early 1990s, depository institution demand for balances at the Federal Reserve was high and relatively stable. This environment facilitated the conduct of open market operations. High required reserves created a stable, predictable demand for reserve balances, so the Desk could more readily achieve the FOMC's reserve market objective by manipulating the supply of reserve balances. Moreover, high required reserve balances and the averaging method used to satisfy them allowed depository institutions to manage their daily account balances flexibly, thus helping to smooth the federal funds rate. ${ }^{11}$

The size of the balance that a depository institution wants to hold at the end of the day in most cases is either its required reserve balance (plus perhaps a desired amount of excess reserves) or the balance it chooses to hold to protect itself against unanticipated debits that could leave its account overdrawn at the end of the day-its payment-related demand. When required reserve balances are high relative to payment-related balances, depository institutions have a great deal of flexibility in managing their daily account balances because they can substitute a balance held on one day for a balance held on another day. ${ }^{12} \mathrm{~A}$ depository institution that finds its balance at the Federal Reserve unexpectedly high on one day (for instance, because a customer made an unexpected deposit or an expected payment was not made)

11. A depository institution's required reserve balance is the difference between its required reserves and its applied vault cash.

12. The degree of substitutability is more limited on the final day of the maintenance period because reserve carryover rules control the extent to which deficient or excess balances may be carried into the next maintenance period. 
does not have to offer to lend the extra balance at very low rates; it can absorb the surplus by choosing to hold lower balances over the remainder of the period and still meet its balance requirement. ${ }^{13}$ Holding a lower balance on a subsequent day of the period does not necessarily increase the likelihood that the depository institution will incur an overnight overdraft because its targeted balance is still high relative to its payment-related demand for balances. This flexibility in managing account balances buffers variations in reserve demand and supply that would otherwise put pressure on the federal funds rate.

Before the early 1990s, the demand for balances to meet reserve requirements was well above the payment-related demand for balances. Imbalances between the daily supply of and demand for reserves could be relatively sizable without affecting the federal funds rate as long as cumulative-average balances were close to period-average requirements. For example, unexpected deviations of reserve supply from projections generally did not create volatility in the federal funds market until near the end of the reserve maintenance period.

\section{Innovations Reducing Required Reserve Balances}

In recent years, the level of required reserve balances has been trending down (chart 1, top panel), for several reasons.

\section{Cuts in Reserve Requirement Ratios}

In the early 1990s, sharp declines in required reserve balances followed two cuts in reserve requirement ratios by the Federal Reserve: ${ }^{14}$ In December 1990, the ratio for nontransaction deposits was reduced from 3 percent to zero, and in April 1992, the ratio

13. A depository institution's end-of-day balances during a reserve maintenance period must at least average its balance requirement, and any deficiency may be subject to a charge. The charge is 2 percentage points above the lowest discount rate in effect for borrowing from its Federal Reserve Bank on the first day of the month in which the deficiency occurred. Reserve carryover rules permit the depository institution to carry over a deficiency (or surplus) of up to 4 percent of its required reserves into the next maintenance period. Any deficiency that cannot be carried over is subject to charge immediately. If the depository institution fails to cover the deficiency that was carried over to the subsequent period, the deficiency charge applies to that portion as well.

14. The subsequent rebounds in these balances reflected strong growth in transaction deposits due in part to falling market interest rates.
1. Required balances at Federal Reserve Banks, 1984-97

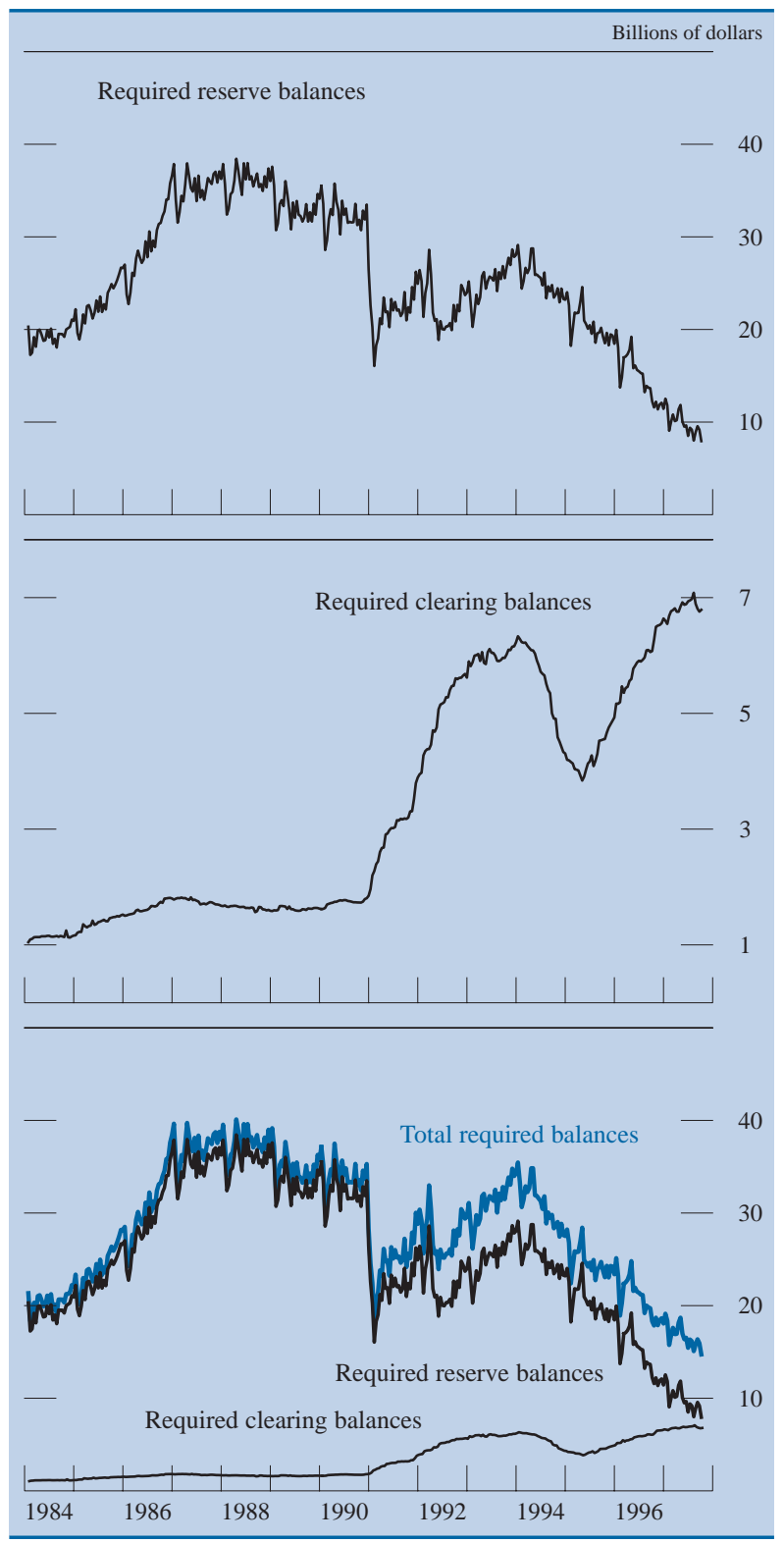

Note. Maintenance-period averages, not seasonally adjusted; 1997 data through September 24.

for transaction deposits was reduced from 12 percent to 10 percent. ${ }^{15}$ The cuts had little effect on the amount of vault cash held by depository institutions, which depends largely on customer needs for currency, so most of the reductions in required reserves were reflected in lower required reserve balances. Each of the cuts trimmed required reserve balances about one-third.

15. The reasons these cuts were made and their implications are discussed in Feinman, "Reserve Requirements: History, Current Practice, and Potential Reform." 


\section{Initiation of Retail Sweep Programs}

More recently, depository institutions have reduced the amount of balances they must hold at the Federal Reserve by instituting retail sweep programs. Under such a program, a depository institution shifts funds from a depositor's reservable transaction deposit (a checking account) to that depositor's nonreservable account (in most cases a money market deposit account). (See box "Retail Sweep Programs.") By doing so, the depository institution decreases the level of its deposits subject to reserve requirements and, with no change in its vault cash holdings, its required reserve balance, on which it earns no interest. A sweep program is profitable because the depository institution can invest the balances formerly held as reserves in interest-earning assets.

Retail sweep programs were first implemented in January 1994, and since then they have spread to most large depository institutions. The total amount of reservable deposits initially swept under such

\section{Retail Sweep Programs}

In a retail sweep program, a depository institution sweeps amounts above a predetermined maximum level from a depositor's checking account (either a demand deposit or an interest-bearing checking account) into a specialpurpose money market deposit account (MMDA) created for the depositor. If the balance in the checking account falls below some minimum level, funds are moved from the MMDA back into the checking account to bring the checking account balance to the specified maximum level. The maximum and minimum levels are set by the depository institution on the basis of the depositor's pattern of activity. Regulations limit the number of automatic transfers from an MMDA to six a month, so upon the sixth transfer the remaining funds in the depositor's MMDA are swept back into the checking account.

Retail sweep programs, which were initiated in January 1994, differ from wholesale sweep programs, which have been in existence since the 1970s. In a wholesale sweep, a depository institution sweeps funds in a business's demand deposit account into one of several types of money market instruments, such as repurchase agreements, Eurodollar deposits, or money market mutual funds. For wholesale sweeps, the instruments into which business deposits are swept may or may not be liabilities of the depository institution; for retail sweeps, on the other hand, the swept funds remain on the books of the depository institution. programs reached an estimated \$226 billion in August 1997. ${ }^{16}$ As a consequence, required reserves declined nearly $\$ 21$ billion, or one-third, between December 1993 and August 1997. Sweep programs lower the balance a depository institution must hold to meet its reserve requirement; in some cases, they lower the required reserve balance so much that it falls to zero because the depository institution's vault cash is more than sufficient to satisfy its reserve requirement. In the aggregate, required reserve balances dropped nearly $\$ 20$ billion, or 70 percent, between December 1993 and August 1997.

\section{The Response of Required Clearing Balances}

For many depository institutions, the cuts in reserve requirement ratios and the introduction of sweep programs have brought their reserve-requirementrelated demands for balances below their paymentrelated demands. For such an institution, setting a target end-of-day balance equal only to its required reserve balance would provide insufficient protection against overnight overdrafts, yet setting a target balance equal to its payment-related demand would result in excess reserves, on which it earns no interest. The institution may have another alternative: Any depository institution that uses Federal Reserve priced services (such as check clearing or electronic payment services) may establish a required clearing balance at its Federal Reserve Bank. The institution contracts with the Reserve Bank to hold a specified level of balances on average during the reserve maintenance period. ${ }^{17}$ In return, the depository institution earns implicit interest, in the form of earnings credits, on balances held to satisfy its clearing balance requirement. It may use the earnings credits to defray the cost of the Federal Reserve services it uses. If the depository institution fails to maintain its contracted clearing balance, on average, over the maintenance

16. The Federal Reserve does not collect data on the actual amount of deposits swept each day. Nor does it officially collect information on the initiation of retail sweep programs. It learns about the initiation of programs through notification by depository institutions and through routine inspection of deposit data submitted by depository institutions. It obtains estimates of initial amounts swept directly from the depository institutions or from the deposit data and then sums these estimates to arrive at a total.

17. The Federal Reserve will also impose a required clearing balance on any depository institution that has a history of repeated overnight overdrafts. 
period, the deficiency is subject to a charge. ${ }^{18}$ Required clearing balances are similar to required reserve balances in that they establish an average balance that must be maintained over the reserve maintenance period. For this reason, required clearing and required reserve balances are often summed, and that sum is referred to as total required balances.

The use of required clearing balances has grown considerably since 1990 (chart 1, middle panel). These balances rose sharply in response to the 1990 cut in reserve requirement ratios and the general downtrend in market interest rates occurring at that time. ${ }^{19}$ More recently, depository institutions that implemented sweep programs increased their required clearing balances an estimated $\$ 31 / 3$ billion between January 1994 and August 1997. The rise in required clearing balances has not matched the decline in required reserve balances, however, in part because depository institutions do not need as large a cushion to protect against overnight overdrafts as was once provided by their required reserve balance. Also, the growth of required clearing balances at some depository institutions is limited by the extent to which the institution uses Federal Reserve priced services. ${ }^{20}$ Thus, the drop in total required balances at the Federal Reserve is smaller than the decline in required reserve balances. However, total required balances remain at historically low levels (chart 1, bottom panel) and are likely to decline somewhat further as additional depository institutions implement retail sweep programs.

18. The penalty for failing to meet the required clearing balance, after application of the so-called clearing balance band, is 2 percent per annum on any deficient amount that is 20 percent or less than the contracted clearing balance requirement and 4 percent per annum on any remaining deficiency. The clearing balance band exempts from charge 2 percent of the contracted clearing balance or $\$ 25,000$, whichever is greater.

19. Required clearing balances are sensitive to the level of interest rates because the earnings credits generated from the clearing balance are calculated using the period-average effective federal funds rate. For a more detailed discussion of required clearing balances, see E.J. Stevens, "Required Clearing Balances," Federal Reserve Bank of Cleveland Economic Review, vol. 29 (1993 Quarter 4), pp. 1-14.

20. A depository institution is better off holding excess reserves, which can be adjusted daily, than contracting to hold a required clearing balance that generates more credits than it can use. The opportunity cost of holding excess reserves and excess clearing balances is the interest forgone on those balances, but the clearing balance locks the depository institution into holding a specified amount during the maintenance period and makes any deficiency subject to a charge. Depository institutions have one year to use the credits earned during a maintenance period.
The Current Environment: Low Total Required Balances

Low total required balances give depository institutions less flexibility in managing their daily balance positions and thus do not provide a buffer for the federal funds rate as high total required balances do. When its total required balance is low, a depository institution is less able to substitute balances across days of the maintenance period. It is less likely to hold a balance above its total required balance because its ability to target lower balances on subsequent days is constrained by the increased risk of an overnight overdraft; therefore, it will actively seek to lend any extra balances, on which it earns no interest, even if the funds rate is already low. It is also less likely to tolerate a balance below its total required balance because it is more likely to be close to an overdraft; therefore, it will seek to borrow balances, and even a small shortfall can trigger aggressive bidding for balances at the Federal Reserve that can, in turn, push up the federal funds rate. ${ }^{21}$

In addition, when a depository institution's total required balance is low, its targeted balance at the Federal Reserve is likely to fluctuate more from day to day. Its payment-related demand for balances may more often exceed its demand for balances to meet its total balance requirement. Payment-related demand is a precautionary demand for end-of-day balances that must be met each day, and the magnitude of that demand depends on the uncertainty about the size and timing of payments flowing through the institution's Federal Reserve account. ${ }^{22}$ The uncertainty appears to be related to the volume of the payments. This volume likely fluctuates considerably each day, as suggested by the aggregate data shown in chart 2 . With uncertainty varying from one day to the next, a depository institution's payment-related demand and

21. An overnight overdraft is charged at an annual rate equal to the day's effective federal funds rate plus 4 percentage points. If the depository institution incurs more than three overnight overdrafts in a moving twelve-month period, the spread over the funds rate rises by 1 percentage point for each additional overdraft.

22. At the end of the day, depository institutions still face some uncertainty about their final balance. Responses to the Federal Reserve's May 1996 Senior Financial Officer Survey indicated that the posting of off-line transactions after the close of the electronic funds transfer system and the possibility that corrections to earlier entries might result in a lower balance were very important reasons for not targeting a lower end-of-day balance in their Federal Reserve accounts. 
2. Daily change in total volume of credits posted to the Federal Reserve accounts of all depository institutions, November 1996-January 1997

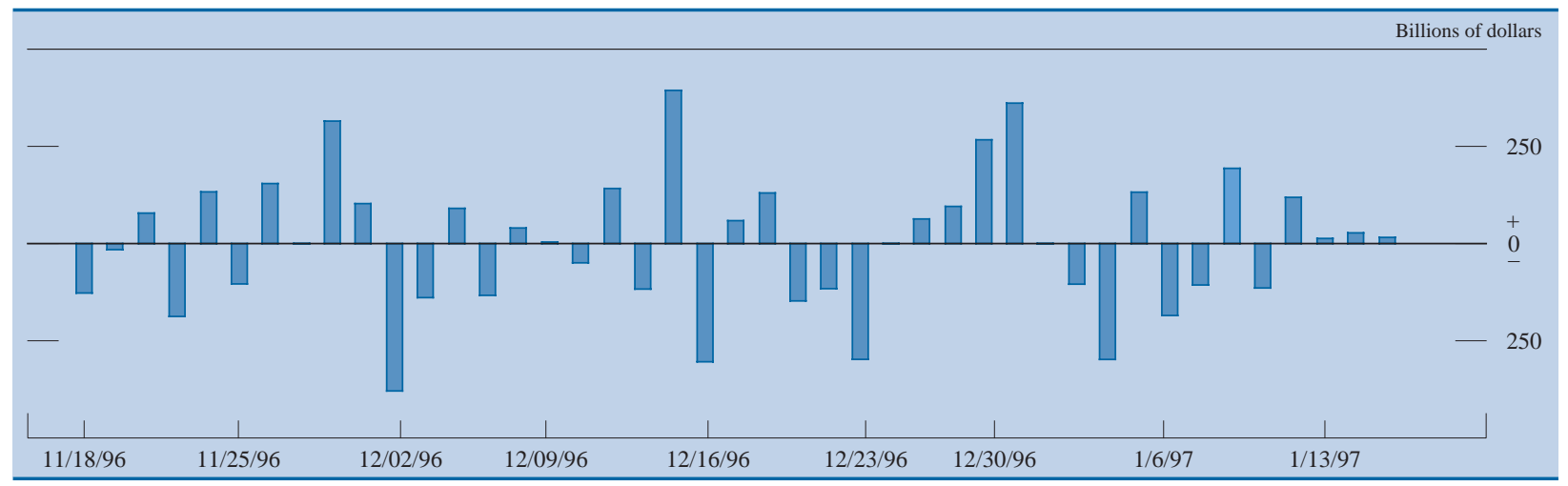

its targeted balance at the Federal Reserve can vary substantially each day as well.

\section{Implications for Open Market Operations}

The Desk attempts to attain a level of nonborrowed reserves over a reserve maintenance period that is consistent with the FOMC's targeted federal funds rate. When planning open market operations, it has always paid attention to the daily pattern of reserve needs. Now, with total required balances low, the daily estimates are playing an even more important role in decisionmaking. The Desk now also reviews forecasts of the total amount of balances at the Federal Reserve for the day and for future days. During maintenance periods when total required balances are especially low, the Desk conducts open market operations to smooth low points in the estimated daily level of total balances. In addition, as it always has, it attempts to supply more reserve balances on days when the payment-related demand for balances is expected to be elevated. These additional considerations have resulted in an increase in the number and volume of overnight repurchase agreements arranged in 1996 and thus far in 1997 (table 4). ${ }^{23}$ An overnight operation is a more effective means of fine tuning the daily level of balances than is a term or outright operation and better addresses heightened paymentrelated demands.

There is indirect evidence that on certain days payment-related demand is an especially important

23. An overnight operation matures on the next business day. The increased use of overnight repurchase agreements is also discussed in "Open Market Operations during 1996," Federal Reserve Bulletin, vol. 83 (July 1997), pp. 565-74. determinant of the total demand for balances at the Federal Reserve. Data on credits posted to the Federal Reserve accounts of depository institutions suggest that payment flows are heaviest on the first business day, the fifteenth calendar day, and the last business day of the month. On these days, depository institutions face more uncertainty about their end-ofday balances. Some depository institutions respond by targeting a higher balance. The Desk seeks to provide balances more generously on these days. However, the exact magnitude of payment-related demand is hard to measure and to estimate. Moreover, even if it were to supply a quantity of balances that exactly matched aggregate demand, the Desk could not ensure that the supply to each institution would exactly match its demand. For these reasons, the federal funds rate may exceed the FOMC's target on these days. Generally, however, the Desk is able to keep the effective federal funds rate (the volumeweighted average rate paid on all transactions during the day) close to the FOMC's target rate.

4. Temporary open market operations, 1990-97

\begin{tabular}{|c|c|c|c|c|c|c|}
\hline \multirow[b]{2}{*}{ Year } & \multicolumn{2}{|c|}{$\begin{array}{l}\text { Overnight } \\
\text { repurchase } \\
\text { agreements }\end{array}$} & \multicolumn{2}{|c|}{$\begin{array}{c}\text { Term } \\
\text { repurchase } \\
\text { agreements }\end{array}$} & \multicolumn{2}{|c|}{$\begin{array}{l}\text { Matched } \\
\text { sale-purchase } \\
\text { transactions }\end{array}$} \\
\hline & $\begin{array}{l}\text { Number } \\
\text { of } \\
\text { market } \\
\text { entries }\end{array}$ & $\begin{array}{c}\text { Volume } \\
\text { (billions } \\
\text { of } \\
\text { dollars) }\end{array}$ & $\begin{array}{c}\text { Number } \\
\text { of } \\
\text { market } \\
\text { entries }\end{array}$ & $\begin{array}{c}\text { Volume } \\
\text { (billions } \\
\text { of } \\
\text { dollars) }\end{array}$ & $\begin{array}{c}\text { Number } \\
\text { of } \\
\text { market } \\
\text { entries }\end{array}$ & $\begin{array}{c}\text { Volume } \\
\text { (billions } \\
\text { of } \\
\text { dollars) }\end{array}$ \\
\hline 1990 & 93 & 253.5 & 34 & 136.4 & 22 & 76.8 \\
\hline 1991 & 108 & 320.2 & 34 & 188.5 & 34 & 78.8 \\
\hline 1992 & 89 & 254.5 & 56 & 278.9 & 20 & 28.6 \\
\hline 1993 & 83 & 266.7 & 82 & 361.0 & 5 & 10.9 \\
\hline 1994 & 80 & 217.6 & 66 & 257.1 & 5 & 13.1 \\
\hline 1995 & 68 & 206.3 & 61 & 248.8 & 17 & 48.6 \\
\hline 1996 & 92 & 347.5 & 70 & 250.3 & 23 & 52.9 \\
\hline 1997 & 91 & 351.5 & 59 & 296.5 & 0 & \\
\hline
\end{tabular}

Note. Data for 1997 are through September 24. 


\section{Implications for the Federal Funds Rate}

Low total required balances, together with the difficulty of gauging the size of payment-related demand, can lead to greater volatility in the federal funds rate, both during a day and across days. ${ }^{24}$ For example, the 1990 cut in reserve requirement ratios brought required reserve balances below the payment-related demand for balances, and funds rate volatility rose significantly (chart 3 ). The time between the announcement and implementation of the cut was quite short. Many large depository institutions had no experience managing their end-of-day balances at the Federal Reserve with total required balances as low as they were after the cut. Depository institutions responded by holding on to their balances until late in the day, when their need for balances to avoid an overnight overdraft became clearer. The funds rate would remain above the FOMC's target until that time, and then, when depository institutions entered the market to try to lend their excess balances, it would drop sharply. At the same time, the acute reluctance of depository institutions to borrow at the discount window also contributed to the volatility. On days when balances were in short supply, depository institutions

24. See James A. Clouse and Douglas W. Elmendorf, "Declining Required Reserves and the Volatility of the Federal Funds Rate," Finance and Economics Discussion Series Paper 1997-30 (Board of Governors of the Federal Reserve System, Divisions of Research and Statistics and Monetary Affairs, June 1997). The authors present a model of a depository institution's demand for balances that distinguishes requirement-related demand from payment-related demand. They also explore the differing behavior of the funds rate in 1991 and 1996. bid the funds rate to very high levels rather than borrow at the window. ${ }^{25}$

The level at which total required balances can trigger a rise in funds rate volatility is not clear. Since late 1996, for example, total required balances have been below their 1991 levels, yet funds rate volatility has failed to rise significantly. ${ }^{26}$ Apparently, total required balances are sufficiently above the paymentrelated demand for balances to keep the funds rate relatively stable. The payment-related demand for balances is likely lower now than it was in 1991. Depository institutions have improved their own internal information systems as well as their proficiency in using real-time information on the balances in their Federal Reserve accounts available through the Federal Reserve's Account Balance Monitoring System. In addition, the imposition of fees for daylight overdrafts has encouraged depository institutions to manage their balances more closely during the day. In the future, the payment-related demand for balances may continue to fall. Interstate branch banking may contribute to lower payment-related demand because separately chartered affiliate banks of a single bank holding company are being merged into a single interstate branched bank with one Fed-

25. Some of the bidding pressure also came from depository institutions that apparently had little or no collateral on deposit with a Federal Reserve Bank and therefore could not borrow readily. See "Monetary Policy and Open Market Operations during 1990," Federal Reserve Bank of New York Quarterly Review, vol. 16 (Spring 1991), pp. 52-78.

26. See also Paul Bennett and Spence Hilton, "Falling Reserve Balances and the Federal Funds Rate," Federal Reserve Bank of New York Current Issues in Economics and Finance, vol. 3 (April 1997), pp. 1-6.

3. Daily range for the federal funds rate, November 1990-April 1991

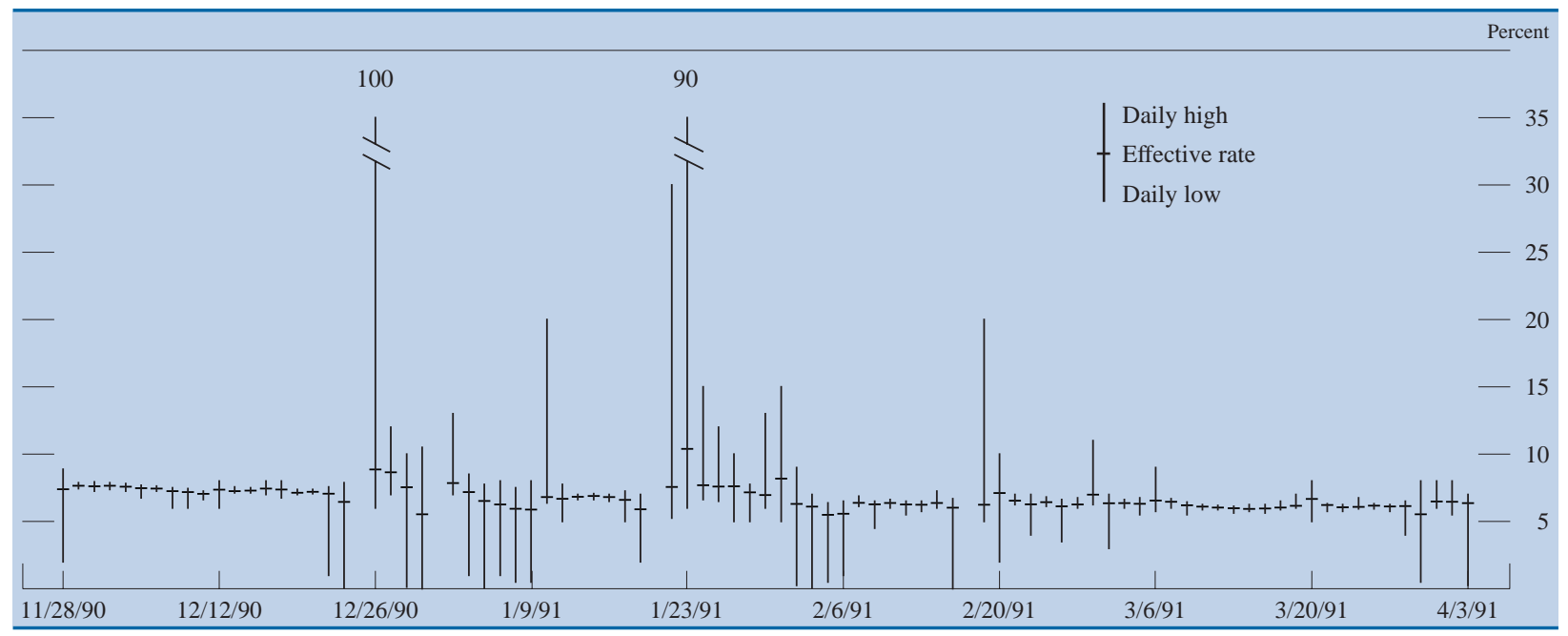

Note. Effective rate is the volume-weighted average rate paid on all transactions during the day. 
5. Daily average volatility of the federal funds rate, 1994-97

Percentage points

\begin{tabular}{c|r|r|r|r}
\hline Measure & 1994 & 1995 & 1996 & 1997 \\
\hline Range _................ & 1.35 & 1.06 & 1.87 & 1.54 \\
Intraday standard deviation ... & .19 & .15 & .23 & .19 \\
Late range _............... & 1.16 & .89 & 1.56 & 1.35 \\
\hline
\end{tabular}

Note. Values for 1997 are based on data through September 24. Range is the difference between the highest and lowest rate at which federal funds lending took place in the brokers market. Intraday standard deviation is a volumeweighted standard deviation of all rates paid in the brokers market. Late range is the difference between the highest and lowest rate at which federal funds lending took place in the brokers market between the close of the New York Clearing House Interbank Payments System (usually 4:30 p.m.) and the close of funds trading (usually 6:30 p.m.)

eral Reserve account. Before interstate branching, each affiliate account had to end the day with a nonnegative balance; under interstate branching, the transactions of all affiliates (now branches) flow through only one account.

The variability in the federal funds rate in recent years is summarized in table 5. In 1996, the daily trading range for federal funds widened, on average, as did an alternative measure, the intraday standard deviation of the funds rate. However, both measures indicate that volatility tapered off during the first nine months of 1997. Overall, the slight increase in the intraday variability of the funds rate has not had adverse effects on the Desk's ability to attain the FOMC's funds rate target; nor has the rise in variability affected other market interest rates more generally.

Additional sweep programs are expected to be implemented, and it is not clear whether their proliferation might eventually lower total required bal- ances to the point that payment-related demand is routinely larger than requirement-related demand. If that does happen, the federal funds rate could become more volatile, and depository institutions may have to change the way they manage their account balances. Especially if that volatility is passed on to other market interest rates, the Federal Reserve might need to alter the way it operates in the funds market. One way to forestall the need to make such changes would be to pay interest on balances held at the Federal Reserve. Payment of a market rate of interest on required reserve balances would virtually eliminate the implicit current tax on depository institutions, likely encouraging some depository institutions to discontinue their sweep programs. However, the payment of interest on Federal Reserve balances requires legislation.

\section{SUMMARY}

Open market operations are the principal tool used by the Federal Reserve to implement monetary policy. They are a powerful and flexible means of fostering conditions in the federal funds market that are consistent with policy objectives. The conduct of open market operations in the 1990s has been shaped by a number of factors, including shifts in the way the FOMC communicates changes in the stance of monetary policy, developments in the market for repurchase agreements, and changes in the demand for balances at the Federal Reserve. In the years ahead, the Federal Reserve will undoubtedly continue to adapt the way it conducts open market operations as financial markets evolve. 